\title{
Biosorption of Copper and Lead from Human Blood Plasma Using allium cepa
}

\author{
Jibunor Victor Udoka ${ }^{1}$, Maaji Paul Sheba ${ }^{2}$, Nnachi Chima ${ }^{3}$, Elebo Abuchi ${ }^{1, ~ * ~}$ \\ ${ }^{1}$ Department of Chemistry, Ahmadu Bello University, Zaria, Kaduna State, Nigeria \\ ${ }^{2}$ Department of Chemical Sciences, Federal University, Wukari, Taraba State, Nigeria \\ ${ }^{3}$ Department of Chemistry, Federal University, Dutsin-Ma, Katsina State, Nigeria
}

Email address:

udokajibunor@gmail.com (E. Abuchi)

${ }^{*}$ Corresponding author

\section{To cite this article:}

Jibunor Victor Udoka, Maaji Paul Sheba, Nnachi Chima, Elebo Abuchi. Biosorption of Copper and Lead from Human Blood Plasma Using Allium cepa. American Journal of Science, Engineering and Technology. Vol. 6, No. 1, 2021, pp. 1-7. doi: 10.11648/j.ajset.20210601.11

Received: September 30, 2020; Accepted: October 19, 2020; Published: March 12, 2021

\begin{abstract}
Lead and Copper are inorganic pollutants that are non-biodegradable. When released into the environment, they have adverse effect on human beings and animals when ingested. Allium cepa (Onion) is a vegetable product largely consumed for its potential therapeutic importance. This study investigates the efficacy of Allium cepa in removal of $\mathrm{Cu}^{2+}$ and $\mathrm{Pb}^{2+}$ from human blood plasma in-vitro. The adsorption rate was studied at optimum values of $\mathrm{pH} 6$ for $\mathrm{Cu}^{2+}$, and $\mathrm{pH} 4$ for $\mathrm{Pb}^{2+}$, metal ion concentration $\left(50 \mathrm{mgL}^{-1}\right)$, and Allium cepa dose $0.60 \mathrm{~g}$ for $\mathrm{Cu}^{2+}$ and $0.40 \mathrm{~g}$ for $\mathrm{Pb}^{2+}$ at physiological temperature $\left(38^{\circ} \mathrm{C}\right)$. SEM analysis revealed physical disintegration in the surface morphology of Allium cepa biomass after adsorption. Equilibrium sorption occurred at 80 mins with $99.316 \%$ removal for $\mathrm{Cu}^{2+}$ and 90 mins with $99.8914 \%$ removal for $\mathrm{Pb}^{2+}$. The adsorption data obtained for $\mathrm{Cu}^{2+}$ best fits Temkin isotherm with correlation value $\left(\mathrm{R}^{2}\right)=0.901$ with low binding energy $\left(\mathrm{A}_{\mathrm{T}}\right)=1.340 \mathrm{Lg}^{-1}$ while the adsorption data for $\mathrm{Pb}^{2+}$ best fits Freundlich isotherm with correlation values $\left(\mathrm{R}^{2}\right)=0.965$ at Freundlich coefficient $\left(\mathrm{k}_{\mathrm{f}}\right)=3.169 .27 \mathrm{Lmg}^{-1}$. The result also revealedthat physiosorption and chemosorption occurred between the metal ions and binding site on the Allium cepa biomass as Intraparticle diffusion proved not to be the only rate controlling step.
\end{abstract}

Keywords: Allium cepa, Biosorption, Freundlich Isotherm, Heavy Metals, SEM and Temkin Isotherm

\section{Introduction}

Chemicals have become an essential part of human life, sustaining activities and development, preventing and controlling many diseases and increasing agricultural yield [1]. Despite their benefits, they can cause adverse effects on human health especially when misused or inappropriately disposed. Heavy metals are among the major constituents of these chemicals. They are harmful been adduced to their nonbiodegradable nature and ability to bioaccumulate in different body parts [2]. When heavy metals enter the human system, they are transported to various part of the body through the blood plasma which is a medium for excretory product transportation [2].

Biosorption is a method that utilizes biological materials to remove heavy metals from aqueous solution. Its advantages over conventional treatment method include low cost, regeneration of biosorbent, possible metal recovery and high efficiency amongst others [1]. Several studies have reported the potential of biological material to bind heavy metals. Amongst these biomaterial is Allium cepathat is highly medicinal [3]. It contains active groups such as carboxylic, sulfate, amino, amide and hydroxyl groups that plays important role in biosorption process [3]. However, lots of biosorption studies have being carried out. For instance Sargassum seaweed as biosorbent for heavy metals [4]; A comparative study on heavy metals biosorption characteristics of some algae [5]; Adsorption of metals by biomaterials derived from the marine alga Ecklonia maxima[6]; Biosorption of cadmium by brown, green and 
red seeweeds [7]; Biosorption of lead and nickel by biomass of marine algae [8]; Biosorption of toxic metals from aqueous solutions by bacteria strains isolated from metalpolluted soils [9]; Biosorption of chromium (VI) from aqueous solution by the husk of Bengal gram (Cicerarientinum) [10]; Biosorption of copper (II) and cobalt (II) from aqueous solution by crab shell particles [11] amongst others.

Copper and lead were selected for this study been adduced to the wide range application in chemical industries. These metals can accumulate along food chain and are nonbiodegradable [9]. Exposure to these metals even at low concentration has adverse effect on human and animal health [2]. This study seeks to investigate the biosorption potential of Allium cepa on $\mathrm{Cu}^{2+}$ and $\mathrm{Pb}^{2+}$ removal from the human blood plasma solution. The effect of $\mathrm{pH}$, biosorbentdoage and metal ion concentration will be optimized and used to study the rate of biosorption. The data obtained will be fitted into Freundlich isotherm, Temkin Isotherm and Intraparticle diffusion model.

\section{Materials and Methods}

\section{Sample Collection and Preparation}

The human blood sample was obtained from the Department of Hematology, Ahmadu Bello University Teaching Hospital, Zaria, Kaduna State, Nigeria. The human blood Plasma was extracted from the human blood sample by centrifugation. The Allium cepa was obtained from samara market, Kaduna state, Nigeria. The Allium cepa bulb was carefully wash with distilled water and rewashed with deionized water, sliced and air dried for a period of 7 days. The dried sample was repeatedly washed with de-ionized water and oven dried for $72 \mathrm{hrs}$ at $60^{\circ} \mathrm{C}$ to a constant mass, pulverized using agate mortar and sieved with a $0.25-0.50$ $\mathrm{mm}$ mesh sieve and stored in an air tight plastic container prior to analysis [12].

Scanning Electron Microscope (SEM) analysis of Allium cepa

The surface morphology was determined before and after biosorption using SEM. The adsorbent was glued to $10 \mathrm{~mm}$ diameter metal mounts and coated with gold under vacuum in an argon atmosphere. The data was recorded over a selected area of the surface of the sample and a two dimensional image was generated as described by [13].

Assessment of $\mathrm{Cu}^{2+}$ and $\mathrm{Pb}^{2+}$ in Samples

The samples (Human blood plasma and Allium cepa biomass) were digested respectively using conventional wet acid digestion as described by [12] and the their filtrates analyzed for $\mathrm{Cu}^{2+}$ and $\mathrm{Pb}^{2+}$ respectively using Agilent model 3510 Atomic Adsorption Spectrophotometer (AAS).

\section{Biosorption Data Evaluation}

The percentage sorption of $\mathrm{Cu}^{2+}$ and $\mathrm{Pb}^{2+}$ were determined using equation 1

$$
\text { Biosorption }(\%)=\frac{C o-C e}{C e} \times 100
$$

Where $\mathrm{Co}$ and Ceare the initial and equilibrium $\mathrm{Cu}^{2+}$ and $\mathrm{Pb}^{2+}$ concentrations in human blood plasma respectively. The amount of $\mathrm{Cu}^{2+}$ and $\mathrm{Pb}^{2+}$ removed from the human blood plasma were calculated using equation 2 .

$$
\mathrm{Q} \mathrm{e}=\frac{(C i-C e) v}{m}
$$

Where qe is the amount of $\mathrm{Cu}^{2+}$ and $\mathrm{Pb}^{2+}$ bind onto the biosorbent $\left(\mathrm{mgg}^{-1}\right)$ at equilibrium, $\mathrm{Ci}$ and $\mathrm{Ce}$ are the initial and final concentration of the metal ion in the human blood plasma $\left(\mathrm{mgL}^{-1}\right), \mathrm{V}$ is the volume of the human blood plasma $\left(\mathrm{cm}^{3}\right)$ and $\mathrm{m}$ is the amount $(\mathrm{g})$ of biosorbent used.

\section{Effect of $p H$}

The effect of $\mathrm{pH}$ was studied over a $\mathrm{pH}$ range of 2 to 10 . The study was carried outby introducing $0.60 \mathrm{~g}$ of biosorbent into separate $250 \mathrm{~cm}^{3}$ conical flasks containing $20 \mathrm{~cm}^{3}$ human blood plasma solution spiked with $50 \mathrm{mgL}^{-1} \mathrm{Cu}^{2+}$ and $50 \mathrm{mgL}^{-}$ ${ }^{1} \mathrm{~Pb}^{2+}$ solutions respectively. The $\mathrm{pH}$ of the mixture was adjusted to $\mathrm{pH} 2$ with $0.1 \mathrm{M} \mathrm{HNO}_{3}$. The mixture was agitated for 100 mins at 200rpmusing a rotary shaker as described by [3]. The adsorbent was separated from the mixture with Whatman No 11 filter paper. The filtrate was digested and analyzed for residual $\mathrm{Cu}^{2+}$ and $\mathrm{Pb}^{2+}$ respectively using AAS. An equilibrium $\mathrm{pH} 6$ and 4 was obtained for $\mathrm{Cu}^{2+}$ and $\mathrm{Pb}^{2+}$ respectively for further study.

Effect of Metal ion concentration

Equilibrium metal ion concentration was studied by introducing $0.60 \mathrm{~g}$ biosorbent into $250 \mathrm{~cm}^{3}$ conical flask containing $20 \mathrm{~cm}^{3}$ human blood plasma spiked $20 \mathrm{mgL}^{-1} \mathrm{Cu}^{2+}$ solution. The mixture was adjusted to an equilibrium $\mathrm{pH} 6$ using $0.1 \mathrm{M} \mathrm{HNO}_{3}$ and agitated for $100 \mathrm{mins}$ at $200 \mathrm{rpm}$. The adsorbent was separated from the mixture with Whatman No 11 filter paper. The filtrate was digested and analyzed for residual $\mathrm{Cu}^{2+}$ using AAS. This procedure was repeated for $\mathrm{Cu}^{2+}$ concentrations of $30 \mathrm{mgL}^{-1}, 40 \mathrm{mgL}^{-1}, 50 \mathrm{mgL}^{-1}, 60$ $\mathrm{mgL}^{-1}$ and $70 \mathrm{mgL}^{-1}$ respectively. The entire procedure was repeated using equilibrium $\mathrm{pH} 4$ for $\mathrm{Pb}^{2+}$ concentration. An equilibrium concentration of $50 \mathrm{mgL}^{-1}$ was obtained for both $\mathrm{Cu}^{2+}$ and $\mathrm{Pb}^{2+}$.

\section{Effect of Biosorbent dosage}

Equilibrium biosorbent dosage was studied by introducing $0.20 \mathrm{~g}$ of biosorbent into $250 \mathrm{~cm}^{3}$ conical flask containing 20 $\mathrm{cm}^{3}$ human blood plasma spiked with equilibrium copper concentration $\left(50 \mathrm{mgL}^{-1}\right)$. The mixture was adjusted to equilibrium $\mathrm{pH} 6$ and agitated for $100 \mathrm{mins}$ at $200 \mathrm{rpm}$. The adsorbent was separated from the mixture with Whatman No 11 filter paper. The filtrate was digested and analyzed for residual copper using AAS. This procedure was repeated for biosorbent dosage of $0.40 \mathrm{~g}, 0.60 \mathrm{~g}, 0.80 \mathrm{~g}$ and $1.00 \mathrm{~g}$. This procedure was repeated for $\mathrm{Pb}^{2+}$ using equilibrium $\mathrm{pH} 4$ and equilibrium concentration $\left(50 \mathrm{mgL}^{-1}\right)$. An equilibrium biosorbent dose of $0.60 \mathrm{~g}$ for $\mathrm{Cu}^{2+}$ and $0.40 \mathrm{~g}$ for $\mathrm{Pb}^{2+}$ was obtained.

\section{Rate of biosorption}

Equilibrium sorption rate was investigated by introducing $0.60 \mathrm{~g}$ of biosorbent into $250 \mathrm{~cm}^{3}$ conical flask containing 20 $\mathrm{cm}^{3}$ human blood plasma spiked with equilibrium $\mathrm{Cu}^{2+}$ 
concentration $\left(50 \mathrm{mgL}^{-1}\right)$, adjusted to equilibrium $\mathrm{pH} 6$ using $0.1 \mathrm{HNO}_{3}$ and agitated for $10 \mathrm{mins}$ at $200 \mathrm{rpm}$ with a rotary shaker [14]. The procedure was repeated for $30 \mathrm{mins}, 40$ mins, 50 mins 60 mins, 70 mins, 80 mins 90 mins 100 mins, 110 mins and $120 \mathrm{~min}$. The procedure was repeated for $\mathrm{Pb}^{2+}$ at equilibrium of $\mathrm{pH} 4$, biosorbent dose $0.40 \mathrm{~g}$ and $\mathrm{Pb}^{2+}$ concentration $50 \mathrm{mgL}^{-1}$.

\section{Result and Discussion}

Scanning Electron Microscope (SEM)

SEM micrograph of the native and heavy metal (Copper and Lead) treated biosorbent are presented in Figures 1, 2 and 3. The result revealed an uneven surface texture with a lot of irregularities in the surface morphology for the native biosorbent. The SEM micrographCu ${ }^{2+}$ treated biosorbent showed remarkable physical disintegration resulting to emergence of protrusions and rough surface area which is an evidence ofhigh metal uptake. The SEM micrograph for $\mathrm{Pb}^{2+}$ treated biosorbent showed more disintegration and rough surface than $\mathrm{Cu}^{2+}$ treated biosorbent been adduced to the high surface interaction between the binding sites on the surface of the Allium cepabiomass and $\mathrm{Pb}^{2+}[15]$.

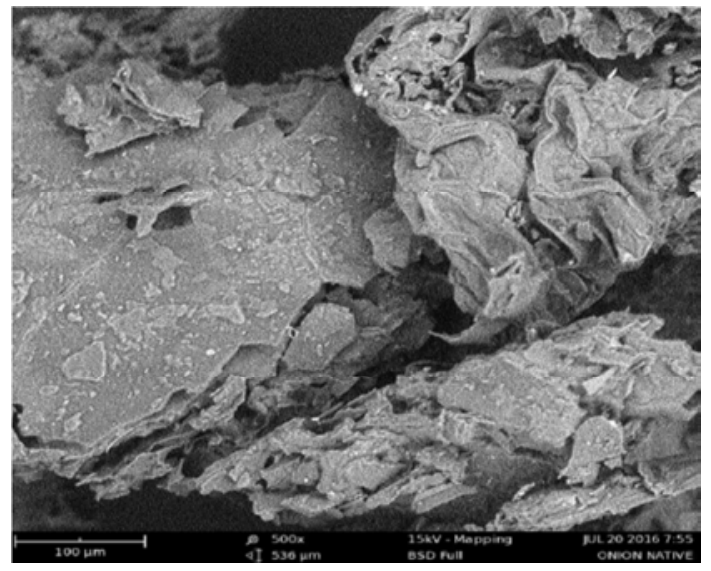

Figure 1. SEM micrograph of Allium cepa Biomass.

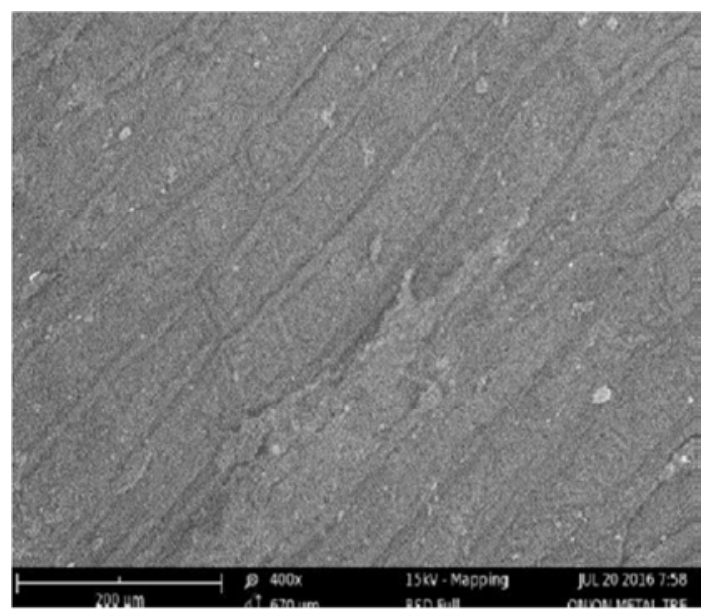

Figure 2. SEM micrograph for copper treated biosorbent.

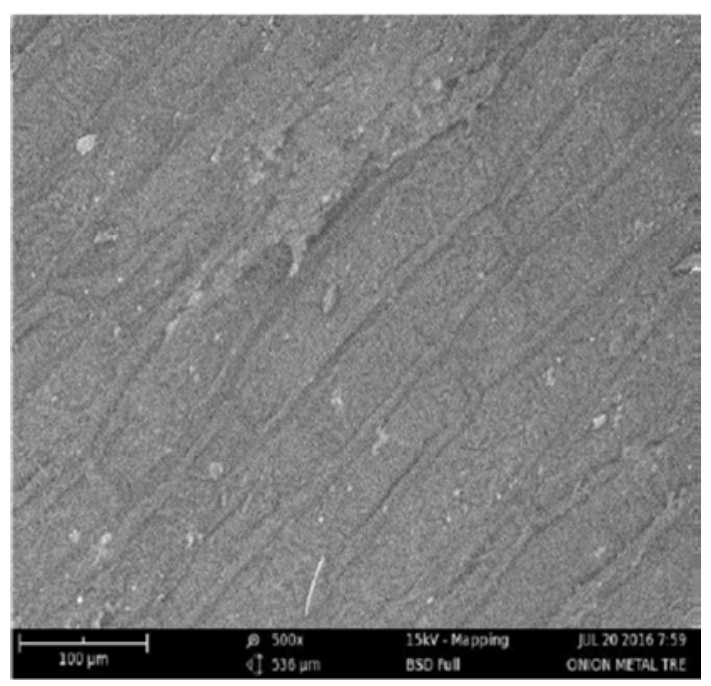

Figure 3. SEM micrograph for lead treated biosorbent.

\section{Equilibrium Adsorption $\mathrm{pH}$}

Effect of $\mathrm{pH}$ on $\mathrm{Cu}^{2+}$ and $\mathrm{Pb}^{2+}$ sorption is presented in Figure 4. The result revealed an increase in percentage removal ofCu${ }^{2+}$ and $\mathrm{Pb}^{2+}$ respectively. The equilibrium sorption was observed at $\mathrm{pH} 6$ for $\mathrm{Cu}^{2+}$ and $\mathrm{pH} 4$ for $\mathrm{Pb}^{2+}$. After equilibrium $\mathrm{pH}$ for the metal ions was attained, desorption occurred with further increase in $\mathrm{pH}$ of the solution which indicates high level of interaction between the metal ions and binding sites on the Allium cepa biomass as the solution tends towards acidic medium.

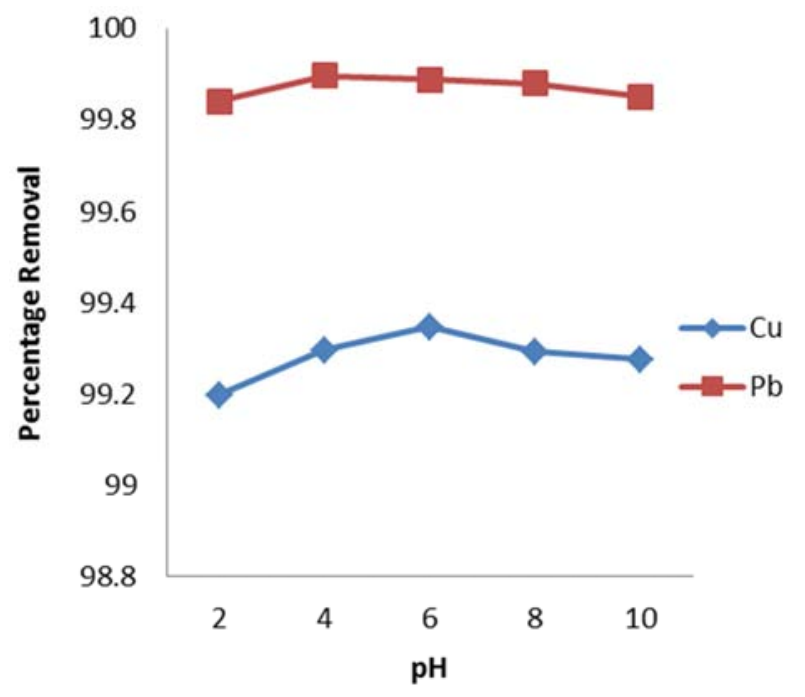

Figure 4. Percentage removal of Copper and Lead as a function of pH.

\section{Effect of Metal ion concentration}

The effect of concentration on $\mathrm{Cu}^{2+}$ and $\mathrm{Pb}^{2+}$ sorption is presented in Figure 5. The result showed an increase in percentage removal from $20 \mathrm{mgL}^{-1}$ to $50 \mathrm{mgL}^{-1}$. The equilibrium concentration for $\mathrm{Cu}^{2+}$ and $\mathrm{Pb}^{2+}$ sorption occurred at $50 \mathrm{mgL}^{-1}$ with percentage removal of $99.19 \%$ and $99.896 \%$ respectively. The data obtained showed a high interaction between the metal ions and the biosorbent [14]. 


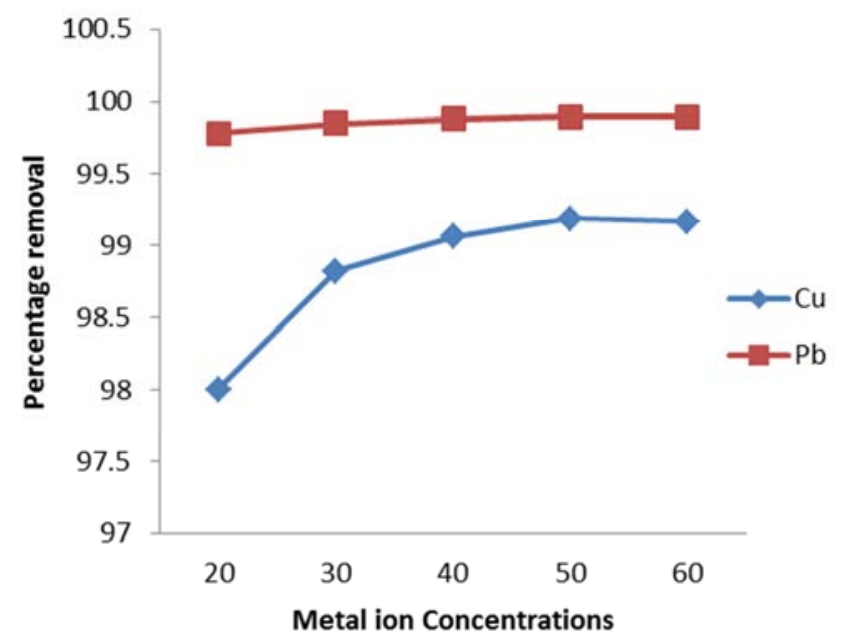

Figure 5. Percentage removal of Copper and Lead as a function of concentration.

\section{Equilibrium Biosorbent dosage}

The result in Figure 6 revealed that maximum sorption of copper and lead occurred at $0.60 \mathrm{~g}$ and $0.40 \mathrm{~g}$ at percentage sorption of $99.34 \%$ and $99.89 \%$ respectively. The result showed that at high biosorbent dosage the available metal ions are insufficient to cover the entire exchangeable site on the biosorbent therefore resulting to low metal sorption [11].

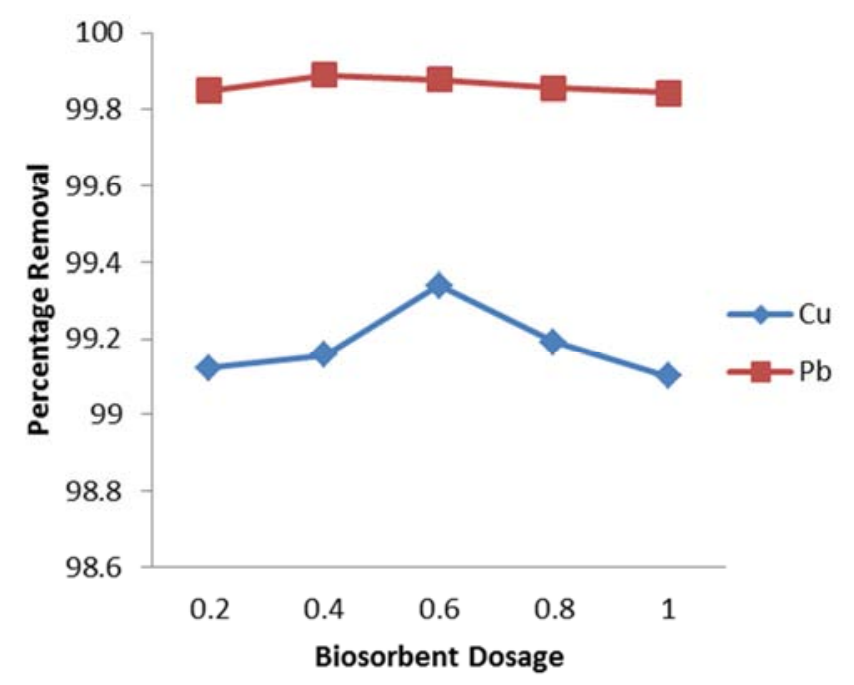

Figure 6. Percentage removal of Copper and Lead as a function of Biosorbent dosage.

\section{Rate of Biosorption}

The effect of contact time on $\mathrm{Cu}^{2+}$ and $\mathrm{Pb}^{2+}$ sorption are presented in Figure 7. The result showed a significant increase in $\mathrm{Cu}^{2+}$ sorption with equilibrium sorption at 80 mins (99.316 \% removal) while $\mathrm{Pb}^{2+}$ sorption showed a slight increase with equilibrium sorption at 90 mins $(99.8914 \%$ removal). Further increase in contact time resulted to release of the adsorbate (Desorption), been adduced to unavailability of free binding cites for metal ion uptake [16].

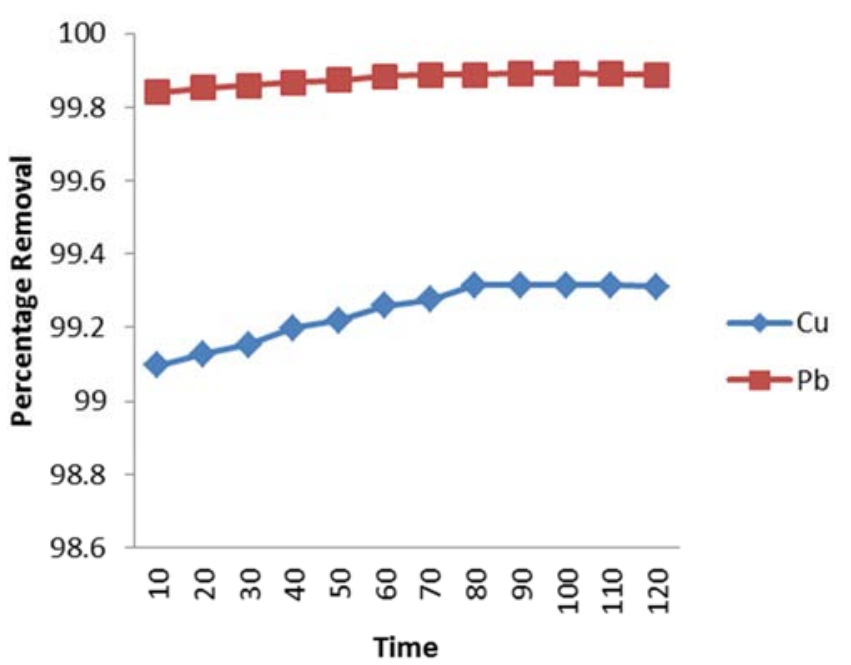

Figure 7. Percentage removal as a function of Time.

\section{Biosorption Isotherm}

The biosorption isotherm reveals the relationship between equilibrium concentration of adsorbate in the solution and the biosorbent at constant temperature [2]. The data obtained from the percentage removal of $\mathrm{Cu}^{2+}$ and $\mathrm{Pb}^{2+}$ with contact time was fitted into Freundlich and Temkin isotherms respectively.

\section{Freundlich Isotherm}

This isotherm model describes non ideal sorption onto heterogeneous surface involving multilayer sorption [15]. The isotherm model is expressed in equation 3

$$
\mathrm{qe}=\mathrm{K}_{\mathrm{f}} \mathrm{C}_{\mathrm{e}}{ }^{1 / \mathrm{n}}
$$

The linearized form is expressed in equation 4

$$
\log Q_{e}=\log K_{f}+1 / n \log C_{e}
$$

Where $\mathrm{Q}_{\mathrm{e}}$ is the amount of adsorbate adsorbed per unit mass of biosorbent, $\mathrm{K}_{\mathrm{f}}$ is the freundlich constant measuring adsorption capacity $(\mathrm{L} / \mathrm{mg}), \mathrm{C}_{\mathrm{e}}$ is equilibrium concentration of the adsorbent in solution $(\mathrm{mg} / \mathrm{L}), \mathrm{n}$ is constant related to adsorption efficiency and adsorption intensity of the biosorbent. $\mathrm{K}_{\mathrm{f}}$ is dependent on the units upon which $\mathrm{Q}_{\mathrm{e}}$ and $\mathrm{C}_{\mathrm{e}}$ are expressed [16].

The Freundlich isotherm for $\mathrm{Cu}^{2+}$ and $\mathrm{Pb}^{2+}$ sorption are presented in Figures 8 and 9 . The result revealed that experimental data obtained for $\mathrm{Cu}^{2+}$ and $\mathrm{Pb}^{2+}$ sorption conforms to Fruendlich isotherm. However the level of conformity is more in $\mathrm{Pb}^{2+}$ as indicated by the correlation coefficient value $\mathrm{R}^{2}=(0.965$ and 0.217$)$ for $\mathrm{Pb}^{2+}$ and $\mathrm{Cu}{ }^{2+}$ respectively. The values of $\mathrm{k}_{\mathrm{f}}(0.3908 \mathrm{~L} / \mathrm{mg}$ and $3,169.57$ $\mathrm{L} / \mathrm{mg}$ ) for $\mathrm{Cu}^{2+}$ and $\mathrm{Pb}^{2+}$ respective indicates that there was a high adsorption of the $\mathrm{Pb}^{2+}$ per cite and a low adsorption of $\mathrm{Cu}^{2+}$ onto the biosorbent surface. The values of $\mathrm{n}$ (5.714 and 0.403 ) for $\mathrm{Cu}^{2+}$ and $\mathrm{Pb}^{2+}$ respectively indicates a favourable $\mathrm{Cu}^{2+}$ sorption and unfavourable $\mathrm{Pb}^{2+}$ sorption since favourable sorption occurs at $1 / \mathrm{n}<1$ [16]. 


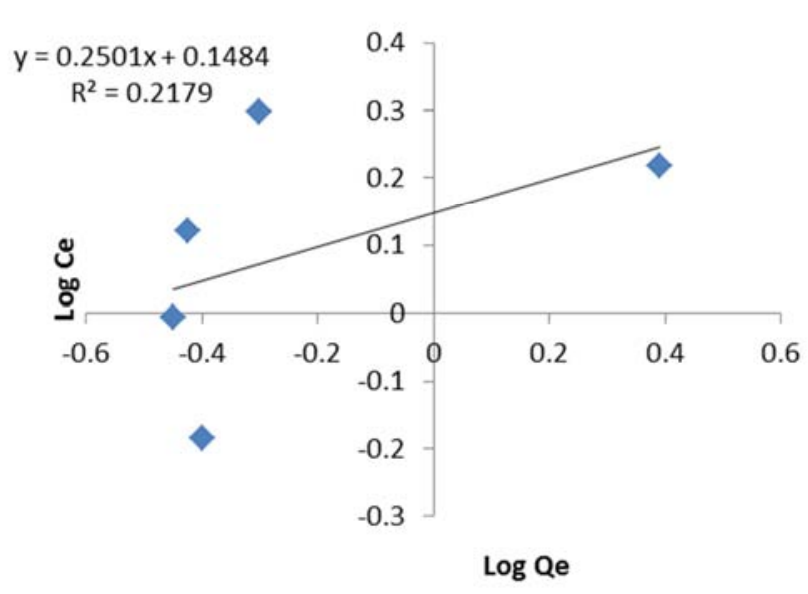

Figure 8. Freundlich isotherm for $\mathrm{Cu}^{2+}$ sorption.

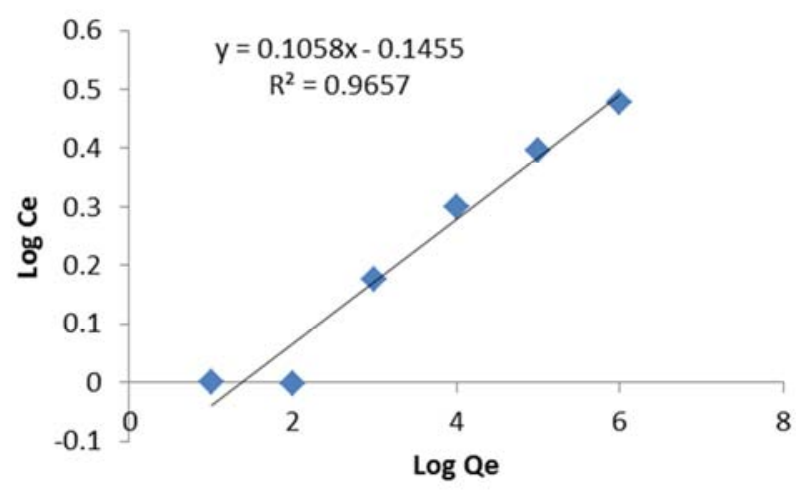

Figure 9. Freundlichisotherm for $\mathrm{Pb}^{2+}$ sorption.

\section{Temkin Isotherm}

Temkin isotherm takes into cognizance the occupation of the more energetic adsorption sites [17]. Besides the low and large magnitude of concentrations, the model assumes that heat of adsorption by all molecules in a layer would decrease linearly rather than logarithmically with coverage [18].

This is as expressed in equation 5

$$
\mathrm{qe}=\mathrm{RT} / \mathrm{b}_{\mathrm{T}} \operatorname{In}\left(\mathrm{AC}_{\mathrm{e}}\right)
$$

The linearized Temkin isotherm is presented in equation 6

$$
\mathrm{qe}=\mathrm{BInA}_{\mathrm{T}}+\mathrm{BInC}_{\mathrm{e}}
$$

where $\mathrm{RT} / \mathrm{bT}=\mathrm{B}, \mathrm{T}(\mathrm{K})$ is the temperature, $\mathrm{R}$ is the ideal das constant $\left(8.314 \mathrm{Jmol}^{-1} \mathrm{~K}^{-1}\right), \mathrm{A}(\mathrm{L} / \mathrm{g})$ is the equilibrium binding energy, B $(\mathrm{J} / \mathrm{mol})$ is a constant related to heat of sorption and $b_{T}$ is the Temkin isotherm constant. The linear plot of qe verse In $\mathrm{C}_{\mathrm{e}}$ is the Temkin isotherm for the biosorption data presented in Figure 10 and Figure 11 for sorption of $\mathrm{Cu}^{2+}$ and $\mathrm{Pb}^{2+}$ respectively. From the result obtained $\mathrm{b}_{\mathrm{T}}=(52.0307$ and 86.220) for $\mathrm{Cu}^{2+}$ and $\mathrm{Pb}^{2+}$ sorption respectively, which suggest a high heat of adsorption [19]. Equilibrium binding energy $\mathrm{A}_{\mathrm{T}}=\left(1.340 \mathrm{Lg}^{-1}\right.$ and $\left.3.90 \mathrm{Lg}^{-1}\right)$ for $\mathrm{Cu}^{2+}$ and $\mathrm{Pb}^{2+}$ respective, indicates low binding energy between the metal ions and the active site on the biosorbent [20]. The correlation coefficient $\mathrm{R}^{2}=(0.901$ and 0.508$)$ values for $\mathrm{Cu}^{2+}$ and $\mathrm{Pb}^{2+}$ respectively indicating conformity to
Temkinisotherm, with $\mathrm{Cu}^{2+}$ showing better fit as indicated by the $\mathrm{R}^{2}=0.901$.

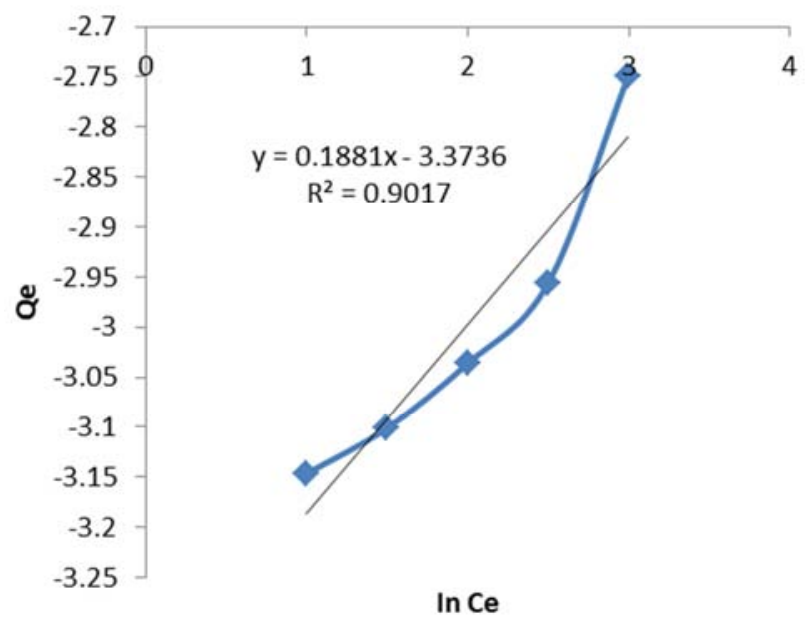

Figure 10. Temkin Isotherm for $\mathrm{Cu}^{2+}$ sorption.

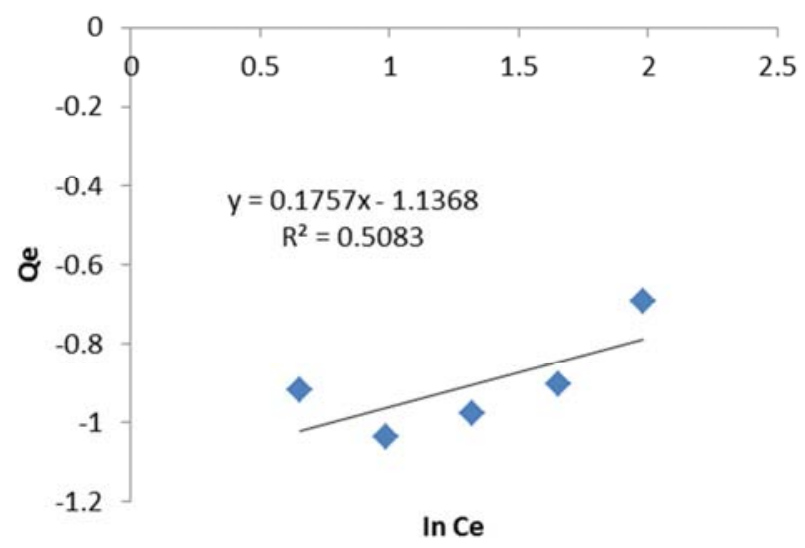

Figure 11. Temkin Isotherm for $\mathrm{Pb}^{2+}$ sorption.

\section{Kinetic Study}

\section{Intraparticle Diffussion}

Intraparticle diffusion is employed to identify diffusion mechanism and rate controlling steps that affect the adsorption process [21]. The rate of Intraparticle diffusion is calculated as expressed in equation 7 .

$$
\mathrm{qt}=\mathrm{k}_{\mathrm{iD}} \mathrm{t}^{1 / 2}+\mathrm{C}_{\mathrm{ID}}
$$

where, $C_{I D}$ is the intercept and $K_{I D}$ is the Intraparticle diffusion rate constant $\left(\mathrm{mg} / \mathrm{g} \min ^{1 / 2}\right)$. A plot of uptake $(q t)$ verse $\left(t^{1 / 2}\right)$ should be linear if Intraparticle diffusion is take place in the adsorption process and if the line passes through the origin then Intraparticle diffusion is the rate determining step [22]. The experimental data obtained for Intraparticle diffusion of $\mathrm{Cu}^{2+}$ and $\mathrm{Pb}^{2+}$ sorption are presented in Figures 12 and 13. The result revealed that a plot of $q t$ verse $t^{1 / 2}$ did not pass through the origin suggesting that Intraparticle diffusion is not the rate determining step [23]. However the data obtained conforms toIntraparticle diffusion as indicated by correlation coefficient value $\mathrm{R}^{2}=(0.900$ and 0.832$)$ for $\mathrm{Cu}^{2+}$ and $\mathrm{Pb}^{2+}$ respectively, with $\mathrm{Cu}^{2+}$ showing best fitas 
indicated by the $\mathrm{R}^{2}=0.900$ for $\mathrm{Cu}^{2+}$ sorption. The positive intercept $C_{i D}=(1.649$ and 1.663) indicates some degree of boundary layer control [24].

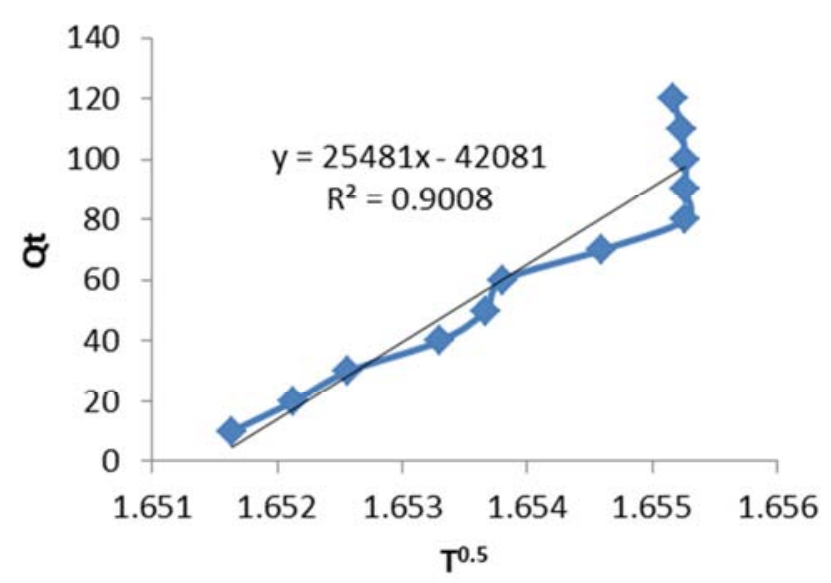

Figure 12. Intraparticle diffusion model for $\mathrm{Cu}^{2+}$ sorption.

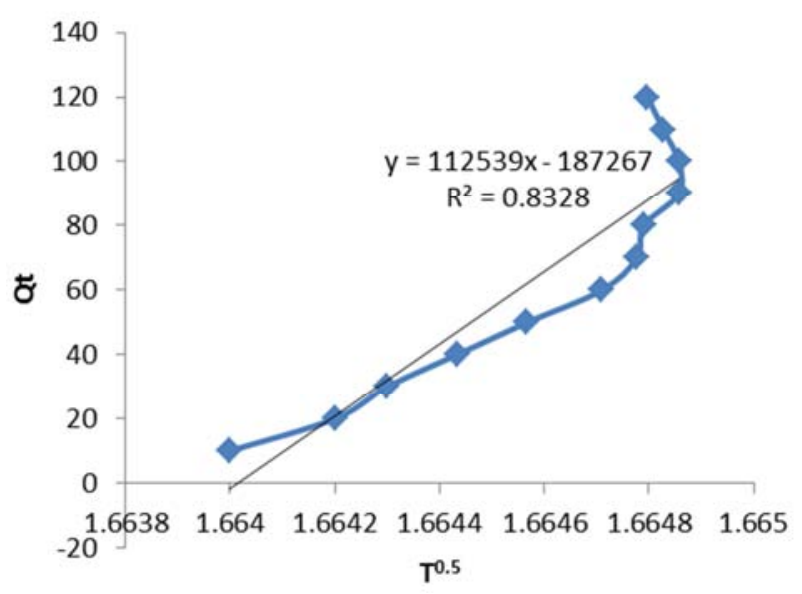

Figure 13. Intraparticle diffusion model for $\mathrm{Pb}^{2+}$ sorption.

Table 1. Isotherm and Kinetic Parameters for Biosorption of $\mathrm{Cu}^{2+}$ and $\mathrm{Pb}^{2+}$.

\begin{tabular}{llll}
\hline \multirow{2}{*}{ Models } & \multirow{2}{*}{ Parameters } & \multicolumn{2}{l}{ Values } \\
\cline { 3 - 4 } Freundlich & $\mathbf{C u}^{2+}$ & $\mathbf{P b}^{2+}$ \\
\hline \multirow{4}{*}{ Temkin } & $\mathrm{K}$ & 0.3908 & $3,169.57$ \\
& $\mathrm{~N}$ & 5.714 & 0.403 \\
& $\mathrm{R}^{2}$ & 0.217 & 0.800 \\
\multirow{3}{*}{ Intraparticle diffusion } & $\mathrm{b}_{\mathrm{T}}$ & 86.220 & 52.0307 \\
& $\mathrm{~A}_{\mathrm{T}}$ & 1.340 & 1.340 \\
& $\mathrm{R}^{2}$ & 0.901 & 0.900 \\
& $\mathrm{~K}_{\mathrm{i}}$ & 0.000 & 0.000 \\
& $\mathrm{C}_{\mathrm{iD}}$ & 1.649 & 1.663 \\
\hline & $\mathrm{R}^{2}$ & 0.900 & 0.832 \\
\hline
\end{tabular}

\section{Conclusion}

This study has revealed that Allium cepabiomass has favourable properties for removal of $\mathrm{Cu}^{2+}$ and $\mathrm{Pb}^{2+}$ from the human blood plasma in-vitro. The biosorption of $\mathrm{Cu}^{2+}$ and $\mathrm{Pb}^{2+}$ was dependent on the $\mathrm{pH}$, concentration of $\mathrm{Cu}^{2+}$ and $\mathrm{Pb}^{2+}$, amount of Allium cepabiomass used and contact time. The biosorption of $\mathrm{Cu}^{2+}$ and $\mathrm{Pb}^{2+}$ was found to be equilibrium at $\mathrm{pH} 6$ for $\mathrm{Cu}^{2+}$ and $\mathrm{pH} 4$ for $\mathrm{Pb}^{2+}$, metal ion concentration of $50 \mathrm{mgL}^{-1}$, biosorbent dose of $0.60 \mathrm{~g}$ for $\mathrm{Cu}^{2+}$ sorption and $0.40 \mathrm{~g}_{\text {for }} \mathrm{Pb}^{2+}$ sorption, contact time of $80 \mathrm{mins}$ for $\mathrm{Cu}^{2+}$ and 90 mins for $\mathrm{Pb}^{2+}$. Temkin and intrapartcle diffusion showed fitted best for the adsorption data of $\mathrm{Cu}^{2+}$ while Freundlich isotherm showed best fitted best for the adsorption data of $\mathrm{Pb}^{2+}$. The information obtained can be useful in heavy metal removal from the human body in-vivo using natural products. However there is need for further study to investigate the effectiveness of Allium cepabiomass in removing copper and lead from human blood plasma invivo.

\section{References}

[1] Sheng, P. X., Ting, J. P., Hong, L., 2004. "Sorption of Lead, Copper, Cadmium, Zinc and Nickel by marine algae biomass: Characterization of biosorptive capacity and investigation of mechanisms", J. Colloind Interface Sci. 275, pp. 131-141.

[2] Ekwumemgbo, P. A., Shallangwa, G. A., Paul, S. M. and Ndukwe, G. I., 2016. "In-vitro decontamination of Lead from human blood plasma using Syzygiumaromaticum biosorbent". The Pacific Journal of Science and Technology, vol 17, no. 2, pp. 250-262.

[3] Griffiths, G., Laurence, T., Brain, T., Timothy, C. and Brian, S., 2002. "Onions- A global benefit of Health", Phytotherapy Research, vol. 16, no. 7, pp. 603-615.

[4] Davis, T. A., Volesky, B., Viera, R. H. S. F., 2000. "Sargassum seaweed as biosorbent for heavy metals. Water Res. 34, 42704278 .

[5] Donmez, G., Aksu, Z., Ozturk, A., Kutsal, T., 1999. “A comparative study on heavy metal biosorption characteristics of come algae", Process Biochem. 34, 885-892.

[6] Feng, D., Aldrich, C., 2004. "Adsorption of heavy metals by biomaterials derived from the marine algae Ecklonia maxima". Hydromatallurgy, 73, pp. 1-10.

[7] Hashim, M. A., Chu, K. H., 2004. "Biosorption of Cadmium by brown, green and red seaweeds. Chem. Eng. J. 97, pp. 249255.

[8] Hola, Z. R., Volesky, B., 1994. Biosorption of Lead and Nickel by biomass of marine algae. Biotech. Bioeng. 43, pp. 1001-1009.

[9] Zouboulis, A. I., Loukidou, M. X., Matis, K. A., 2004. "Biosorption of toxic metals from aqueous solution by bacteria strains isolated from metal polluted soils. Process Biochem. 39, pp. 909-916.

[10] Ahalya, N., Kanmadi, R. D., and Ramachandra, T. V., 2005. "Biosorption of Chromium (IV) from aqueous solution by the husk of Bengal gram (Cicerarientinum). Electroic $J$ Biotechnol, 8, pp. 258-264.

[11] Vijayaraghavan, N., Palanivelu, K., and Velan, M., 2006. "Biosorption of Copper and Cobalt (II) from aqueous solution by crab shell particles, BioresourTechnil, 97, pp. 1411-1119.

[12] Ningchuan, F., Xueyi, G., Sha, L., Yanshu, Z., Jianping, L., 2011. "Biosorption of heavy metals from aqueous solutions by chemically modified orange peel". Journal of Hazardous Materials, 185 pp. 49-54. 
[13] Abdel-Aty, M. A., Nabila, S., Ammar, H. H., Ghafar, A., and Rizka, K. A., 2013. "Biosorption of Cadmium and Lead from aqueous solution by fish water algae Anabaena Sphaerica biomass", Journal of Advance Research, vol. 4, pp. 367-374.

[14] Babarinde, N. A., Babalola, J. O., and Sanni, A. R. A., 2006. Biosortion of Lead ions from aqueous solution by maize leaf, International Journal of Physical Science, 1 (1), 23-26.

[15] Grag, U. K., Kaur, M. P., Garg, V. K., and Sud, D., 2007. "Removal of Hexavalent Chromium from Aqueous solution by agricultural waste. Biomass. J Hazard Mater, 1: 40-60.

[16] Gupta, V. K. and Rastogi, A., 2007. "Sortion and desorption studies of Chromium (VI) from noviablecyanobacterium Nostocmuscorum biomass. Journal od Hazadous Materials; 154 (1-3): 347-354.

[17] Abdel-Ghani, N. T., Henfy, M. and El-Chaghaby, G. A. F., 2007. "Removal of Lead from aqueous solutions using low cost adundantly available adsorbents, International Journal of Environmental Science and Technology, 4 (1), pp. 67-73.

[18] Ozcan, A. S., and Ozcan, A., 2004. Adsorption of acid dyes from aqueous solutions onto acid-activedbentonite", J. Colloid Interface Sci; vol. 276, pp. 39-46.

[19] Kumar, K. V., 2006, “Comparative analysis of linear and non- linear method of estimating the sorption isotherm parameters for malachite green onto activated carbon, Journal of Hazadous Material, vol. 136, no. 2, pp. 197-202.

[20] Al-Jlil, S. A and Latif, M. S., 2013. "Evaluation of Equilibrium Isotherms model for the adsorption of $\mathrm{Cu}$ and $\mathrm{Ni}$ from wastewater on Benronite clay", Material and Technology, vol. 47, no. 4, pp481-486.

[21] Wu, F. C., Tseng, R. L., and Juang, R. S. (2009). Initial behavior of Intraparticle diffusion model used in the description of adsorption Kinetics. Chemical engineering Journal, 153 (1-3), 1-8.

[22] Valderrama, C., Gamisans, X., De lasHeras, X., Farran, A., and Cortina, J. L. (2008). Sorption Kinetics of polycyclic aromatic hydrocarbons removal using granular activated carbon: Intraparticle diffusion coefficients". Journal of Hazadous Materials, 157 (2-3), 386-396.

[23] Cheung, W. H., Szeto, Y. S., and McKay, G. (2007). Intraparticle diffusion processes during acid dye adsorption onto chitosan. Bioresource Technology, 98 (15), 2897-2904.

[24] Ofomaja, A. E. (2010). Intraparticle diffusion process for lead (II) biosorption onto mansonia wood sawdust. Bioresource Technology, 100 (15), 5868-5876. 